\title{
On the Nutritional Value of Edible Insects
}

\author{
Areej Al Khalaf' ${ }^{1}$ and Afaf Elansary ${ }^{2 *}$ \\ ${ }^{1}$ Department of Biology, College of Science, Princess Nora Bint Abdul Rahman University, Saudi Arabia \\ ${ }^{2}$ Central Laboratory, Center for Female Scientific and Medical Colleges King Saud University, Saudi Arabia
}

*Corresponding author: Afaf Elansary, Central Laboratory, Center for Female Scientific and Medical Colleges King Saud University, Saudi Arabia Submission: March 18, 2018; Published: May 16, 2018

\section{Letter to the Editor}

The practice of consuming insects is called entomophily, may help to meet the growing protein demand by humans worldwide. Recently consumption of insects by humans is traditionally practiced in many countries around the world. Over 2000 insect species are edible and has a high nutritional value. Among these species are beetles, caterpillars, bees, ants and flies and other species [1]. The maximum consumption of insects is in Asia, Africa and Latin America [1]. Based on the fact that the nutritional value of insects are comparable to commonly eaten meats. Considering the growing population in the world and the increasing demand for production of traditional beef and chicken meat, edible insects should be seriously considered as a source of animal protein [2]. The most applicable strategy to promote insect consumption is to incorporate the insects unrecognizably into familiar products [3].

Considering the amino acid composition of edible insects, they contain a number of amino acids such as phenylalanine, tyrosine, lysine, tryptophan and threonine which are of great nutritional value especially because some of which are deficient in certain cereal proteins.

Tenebrio molitor, Schistocerca gregaria, Gryllodes sigillatus as three species of insects easily to be breed in Europe were found to have the biggest potential to be used as food and feed [4]. Zielińska et al. [5] reported that these insects could be used as alternative source of protein. Their proteins are highly soluble under a wide $\mathrm{pH}$ range, high emulsion activity and moderate foaming capacity and foam stability which increase the chances to be used as food additives in acid and alkaline food. Moreover, protein hydrolysates or peptides from edible insects was found to have similar or higher nutritional value than that of plants and animals dietary proteins.

The poly unsaturated to saturated fatty acid $(\mathrm{P} / \mathrm{S})$ ratio is one of the most significant markers of lipid composition in a healthy diet. It is recommended to consume diet with a $\mathrm{P} / \mathrm{S}$ ratio close to 1 . A high $\mathrm{P} / \mathrm{S}$ ratio $(\geq 3)$ in diet may promote tumor formation, while a low $\mathrm{P} / \mathrm{S}$ ratio $(\leq 0.33)$ in the diet could be atherogenic [6]. Interestingly, some insects contain lipids with $\mathrm{P} / \mathrm{S}$ ratio (close to one, indicating the strong nutritional potential of their lipids.
The omega 6 to omega 3 fatty acids $(n 6 / n 3)$ ratio is another commonly used index to access healthy diets. Studies have suggested that a high $n 6 / n 3$ ratio in diet is possibly linked to the development of a variety of physiological disorders (such as cancer, coronary heart disease etc.) $[7,8]$.

Artificial diets with high content of linoleic, $\alpha$-linolenic, eicosapentaenoic or docosahexaenoic acids increased the content of these fatty acids in the insect tenfold. To achieve required $\omega-6 / \omega-3$ ratio for human consumption, diverse diets with a source of $\omega-3$ fatty acids and protein should be used when rearing edible insects. This can help to suggest the potential role of optimizing $\omega-6 / \omega-3$ ratio for improving human nutrition through the production of edible insects with designed nutritional content [9].

Application of this concept is very attractive and innovation is kept improving in this regard. Most recently, 3D printing technology was employed to obtain snacks with a designed cylindrical geometry from wheat flour dough enriched by ground larvae of yellow mealworms (Tenebrio molitor) as novel source of proteins $[9,10]$.

In addition to their high nutritional values, edible insects have also been found beneficial in treating many diseases such as anemia, respiratory disorder, gastrointestinal diseases and $[1,4]$. Few edible insects namely mealworm (Tenebrio molitor Linnaeus), superworm (Zophobas atratus (Fabricius)) and cricket (Gryllus assimilis (Fabricius) can be used as complementary medicine in treating people suffering with hyper uricemia or gout as these insects are the sources of low-purine and protein-rich diet [5]. Reports have also suggested that aqueous extract of Vespa affinis may be used as therapeutics against oxidative stress-associated health disorders [6]. Recently it has been found that consumption of insects like Grasshoppers, Crickets and Mealworms species could be exceptional sources of bio available iron and it could increase the minerals ( $\mathrm{Ca}, \mathrm{Cu}, \mathrm{Mg}, \mathrm{Mn}, \mathrm{Zn}$ etc.) intake in the human diets [7].

The interest of further more detailed research in the area of 
nutritional value of edible insects may lead to discovery of novel peptide sequences, PUFAs which may be more potent and/or more bio available than those present in conventional diet. In accordance, Entomophagy may become a "norm" around the world in the future especially in the third world poor country. Therefore, further scientific evaluation of understudied edible insects is critically needed in order to better understand the potential of edible insects in human health.

\section{References}

1. Jongema Y (2017) World list of edible insects. Taxonomist at the Department of Entomology of Wageningen University \& Research, Netherlands.

2. Dreon AL, Paoletti MG (2009) The wild food (plants and insects) in Western Friuli local knowledge (Friuli-Venezia Giulia, North Eastern Italy). Contrib Nat Hist 12: 461-488.

3. Van Huis A (2017) New sources of animal proteins: edible insects. New Aspects of Meat Quality, Woodhead Publishing Series in Food Sciences, Technology and Nature, pp. 443-461.

4. EFSA Scientific Committee (2015) Risk profile related to production and consumption of insects as food and feed. EFSA Journal 13(10).
5. Zielińska E, Karaś M, Baraniak B (2018) Comparison of functional properties of edible insects and protein preparations thereof. LWT - Food Science and Technology 91: 168-174.

6. Turley J, Thompson J (2015) Nutrition: your life science. In: Turley J, Thompson J (Eds.), Nutrition: your life science. $\left(2^{\text {nd }} e d n\right)$, Cengage Learning, UK.

7. Bophimai P, Siri S (2010) Fatty acid composition of some edible dung beetles in Thailand. Int Food Res J 17: 1025-1030.

8. Milićević D, Vranić $\mathrm{D}$, Mašić Z, Parunović N, Trbović D, et al. (2014) The role of total fats, saturated/unsaturated fatty acids and cholesterol content in chicken meat as cardiovascular risk factors. Lipids Health Dis 13: 42.

9. Severini C, Azzollini D, Albenzio M, Derossi A (2018) On printability, quality and nutritional properties of 3D printed cereal based snacks enriched with edible insects. Food Res Int 106: 666-676.

10. Nongonierma AB, FitzGerald RJ (2017) Unlocking the biological potential of proteins from edible insects through enzymatic hydrolysis: A review. Innovative Food Science and Emerging Technologies 43: 239-252.
Creative Commons Attribution 4.0 International License

For possible submissions Click Here

\section{Submit Article}

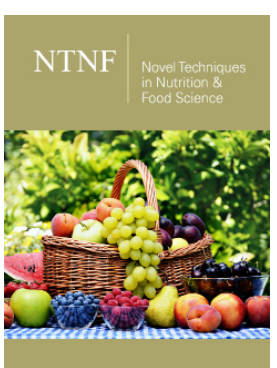

Novel Techniques in Nutrition and Food Science

\section{Benefits of Publishing with us}

- High-level peer review and editorial services

- Freely accessible online immediately upon publication

- Authors retain the copyright to their work

- Licensing it under a Creative Commons license

- Visibility through different online platforms 